\title{
SISTEM INFORMASI PERSEDIAAN ALAT TULIS KANTOR STUDI KASUS PADA PT BANK MUAMALAT INDONESIA CABANG PEKANBARU
}

\author{
Doni Winarso, Aryanto \\ Fakultas Ilmu Komputer Universitas Muhammadiyah Riau
}

\begin{abstract}
Abstrak - PT.Bank Muamalat Indonesia Tbk merupakan perusahaan yang bergerak di bidang perbankan. seperti halnya perusahaan-perusahaan lainnya PT.Bank Muamalat juga mempunyai persediaan alat tulis kantor untuk mendukung kelancaran aktivitas bisnisnya. ketika penelitian ini dilakukan pencatatan dan pembuatan laporan masih dilakukan menggunakan sistem manual atau setidaknya menggunakan software Microsoft Office Excel sebagai alat hitung. atas permasalahan tersebut maka dilakukanlah penelitian yang di beri judul Sistem Informasi Persediaan Alat Tulis Kantor studi kasus pada PT.Bank Muamalat Indonesia cabang Pekanbaru.

Penelitian ini menggunakan metode penelitian perangkat lunak, dimana yang pertama sekali dilakukan adalah dengan cara mengidentifikasi masalah yang dilanjutkan dengan studi kepustakaan, pengumpulan data, menganalisa, perancangan kemudian dilanjutkan dengan mengimplementasikan system kedalam bentuk terkomputerisasi, dan terakhir adalah melakukan pengujian terhadap sistem.

Berdasarkan hasil pengujian maka disimpulkan bahwa sistem informasi ini dapat memberikan informasi kepada pihak management yang lebih tepat dan akurat ketika pelaporannya. sistem ini juga sangat membantu bagian sarana logistik dalam mengelola persediaan alat tulis kantor pada PT.Bank Muamalat Indonesia cabang Pekanbaru.
\end{abstract}

kata kunci : Persediaan Alat Tulis Kantor , ATK, laporan, sistem informasi

\section{PENDAHULUAN}

PT. Bank Muamalat Indonesia cabang Pekanbaru saat ini berkembang dengan sangat pesat, hal ini dapat dilihat dari pertumbuhan kantor kas dan kantor cabang pembantu, sampai akhir tahun 2011 sudah ada 7 kantor kas dan 3 cabang pembantu yang berdiri di provinsi Riau. Tentunya perkembangan ini memberikan dampak positif kepada nasabah dikarenakan layanan yang diberikan oleh perusahaan bisa lebih mudah dijangkau. Namun permasalahan baru timbul seiring dengan bertambahnya kantor layanan ini, karena pihak bank harus segera mempersiapkan diri dalam hal pelayanan baik pelayanan secara internal maupun eksternalnya.

Tidak berbeda dengan perusahaan perusahaan lainnya PT Bank Muamalat Indonesia juga memiliki stok persediaan alat-alat untuk keperluan kantor, bahkan dengan bertambahnya jumlah kantor kas dan cabang pembantu pengelolaan persediaan barang dan alat tulis kantor dirasa semakin komplek dan membutuhkan perhatian khusus oleh pihak manajemen PT. Bank Muamalat Indonesia cabang pekanbaru.

$\begin{array}{rrrr}\text { Kontrol } & \text { yang } & \text { baik sangat } \\ \text { dibutuhkan } & \text { untuk } & \text { menangani }\end{array}$ permasalahan persediaan ini, karena jika dilihat arus masuk dan keluar barang pada PT. Bank Muamalat Indonesia cabang 
Pekanbaru sudah termasuk besar untuk skala perusahaan. Jika dalam pengelolaan persediaan barang ini ada kesalahan pencatatan tentunya akan memberikan efek yang tidak baik untuk perusahaan bahkan bisa sampai menimbulkan kerugian yang sangat besar. Sebagaimana diketahui bahwa persediaan merupakan investasi yang membutuhkan modal besar dan tentunya juga mempengaruhi pelayanan ke pelanggan. Kebutuhan akan alat tulis kantor oleh setiap staff menjadikan pihak manajemen berupaya untuk memberikan layanan yang terbaik secara internal sehingga, diharapkan dengan ketepatan waktu, keakuratan barang yang diminta dan pelaporan persediaan barang pada akhir bulan bisa diberikan sebaik dan secepat mungkin sehingga berimbas kepada layanan terhadap nasabah, dan tentunya akan mendatangkan keuntungan yang besar bagi pihak PT. Bank Muamalat Indonesia.

Dalam Pengelolaannya persediaan alat tulis kantor ini dikelola oleh bagian Sarana logistik yang bertanggung jawab langsung kepada operation manager. Selama ini pengelolaan persediaan pada PT Bank Muamalat Indonesia cabang Pekanbaru masih dilakukan secara manual, sehingga sering kali keluar masuk barang tidak tercatat sebagai mana mestinya dan menimbulkan selisih antara data bagian persediaan secara fisik dengan data bagian yang ada pada sistem pembukuan perusahaan.

\section{LANDASAN TEORI}

\section{a. Definisi Sistem Informasi}

Sistem pada dasarnya adalah sekelompok unsur yang erat hubungannya antara satu dengan yang lainnya, yang berfungsi bersama-sama untuk mencapai tujuan tertentu (Tata Sutabri, 2004).
Sedangkan menurut Mc Leod (2005) sistem informasi merupakan sistem yang mempunyai kemampuan untuk mengumpulkan informasi dari semua sumber dan menggunakan berbagai media untuk menampilkan informasi.

Sistem informasi dapat didefinisikan sebagai suatu sistem di dalam suatu organisasi yang merupakan kombinasi dari orang-orang, fasilitas, teknologi, media, prosedur-prosedur dan pengendalian yang ditujukan untuk mendapatkan jalur komunikasi penting, memproses transaksi rutin tertentu, memberi sinyal kepada manajemen dan yang lainnya terhadap kejadian-kejadian internal dan eksternal yang penting dan menyediakan suatu dasar informasi untuk mengambil suatu keputusan.

\section{b. Persediaan}

Persediaan merupakan simpanan material berupa bahan mentah, barang dalam proses dan barang jadi. Persediaan diperlukan untuk menjaga kelancaran operasi dalam sebuah perusahaan, selain itu persediaan juga merupakan elemen utama dari modal kerja yang termasuk kedalam aktiva paling produktif dan secara terus menerus mengalami perubahan.

Dalam manajemen persediaan untuk memenuhi kriteria persediaan yang harus diperhatikan adalah yang pertama berupa unit barang yang harus dipesan, limit persediaan yaitu pada jumlah berapa persediaan sudah harus dilakukan pemesan kembali dan jenis persediaan mana yang harus diperhatikan secara khusus.

Persediaan harus dikelola dengan baik oleh suatu perusahaan karena persediaan merupakan investasi yang membutuhkan modal besar, selain itu persediaan berhubungan langsung oleh pelayanan yang akan diberikan kepada nasabah atau pelanggan sehingga dengan begitu secara tidak langsung pastinya akan 
berpengaruh kepada fungsi operasi, pemasaran dan keuangan. Pada akhirnya dapat disimpulkan bahwa persediaan merupakan

1. Persediaan merupakan investasi yang sangat mahal

2. Diperlukan proses yang spesifik untuk mengelola persediaan sehingga membantu dalam hal pengendalian biaya

3. Penghematan biaya persediaan berdampak signifikan terhadap efisiensi biaya perusahaan secara keseluruhan.

Pengertian persediaan berbedabeda tergantung dari jenis perusahaan penggunanya. Jika persediaan yang dikelolanya merupakan persediaan barang jadi, barang dalam proses, persediaan produk jadi maka persediaan ini merupakan persediaan untuk perusahaan manufaktur. Jika perusahaan pemakai persediaan merupakan perusahaan dagang maka persediaan yang dipakainya disebut persediaan barang dagangan yang merupakan barang yang dibeli dan kemudian dijual kembali. Sedangkan untuk perusahaan yang menggunakan persediaan yang digunakan sendiri, dimana prosesnya adalah membeli persediaan kemudian digunakan untuk mendukung kelancaran aktivitas perusahaan maka persediaan ini bisa disebut dengan persediaan alat kantor.

\section{METODE PENELITIAN}

Penelitian ini menggunakan metode pengembangan perangkat lunak dengan model waterfall yang terdiri dari beberapa tahapan, adapun tahapan-tahapannya dapat dilihat dari gambar berikut:

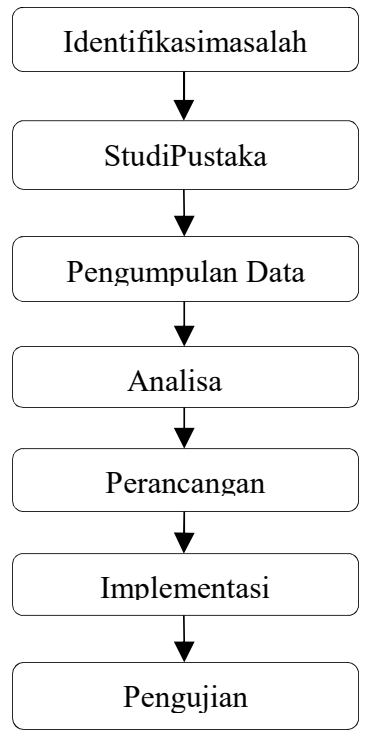

\section{Gambar 1 Tahapan Penelitian}

\section{a. Identifikasi Masalah}

Permasalahan yang ada pada pengelolaan alat tulis kantor pada bank Muamalat Indonesia cabang Pekanbaru adalah belum tersedianya sistem informasi yang mencatat dan mengelola persediaan secara terkomputerisasi.

\section{b. Studi kepustakaan}

Yaitu dengan membaca dan memahami materi yang berhubungan dengan manajemen persediaan barang atau alat tulis kantor.

\section{c. Pengumpulan Data}

Metode pengumpulan data pada penelitian ini dilakukan dengan cara :

1. Melakukan wawancara langsung dengan Bapak Taufik Ginanjar selaku Operation Manager pada PT. Bank Muamalat Indonesia cabang Pekanbaru dan juga dengan Bapak M.Fatir Al-Fattah selaku staff bagian umum yang memegang kendali 
langsung terhadap persedian pada perusahaan ini.

2. Observasi. Tahap ini merupakan tahap pengumpulan data yang akan dijadikan pengetahuan dari sistem yang akan dibuat.

\section{d. Analisa}

Tahap ini merupakan tahap untuk menganalisa bagaimana cara pengelolaan persediaan yang masih manual dialihkan kepada sistem yang telah terkomputerisasi.

\section{e. Perancangan}

Pada tahap ini dirancang sebuah sistem informasi dimana langkah-langkah yang dilakukan adalah:

1. Mendesain database

2. Mendesain interface sistem informasi persediaan

3. Tool yang digunakan dalam perancangan ini adalah diagram konteks (contex diagram), Data Flow Diagram (DFD), Entity Relationship Diagram (ERD) dan kamus data

\section{f. Implementasi}

Pada tahapan implementasi ini merupakan tahapan untuk menerapkan rancangan sistem menjadi perangkat lunak. Pada tahapan ini implementasi menggunakan Database Management System (DBMS) MySQL, bahasa pemrograman VB.net.

\section{g. Pengujian}

Pada tahapan ini dilakukan pengujian terhadap perangkat lunak yang diimplementasikan. Tahapan ini dilakukan pada proses proses yang difasilitasi oleh sistem serta pengujian hasil akhir atau laporan yang dikeluarkan oleh sistem.

\section{HASIL DAN PEMBAHASAN}

\section{a. Analisis Sistem}

Tahapan analisis sistem pada perancangan sebuah sistem informasi baru yang berbasis komputer mempunyai peranan yang sangat penting. Hal ini dilakukan untuk mengetahui dan memahami alur sistem yang akan dibuat, permasalahan yang terjadi pada sistem sebelumnya dan untuk dijadikan dasar dalam pemecahan permasalahan yang akan dituangkan kedalam sistem baru. Dalam sistem informasi persediaan alat tulis pada PT. Bank Muamalat Indonesia ini analisa yang dilakukan adalah memahami dan mencari permasalahan yang terjadi pada proses order barang, pembukuan persediaan dan arus keluar masuknya barang.

Ada beberapa persediaan yang digunakan pada PT Bank Muamalat Indonesia diantaranya adalah :

1. Persediaan Alat Tulis

Persediaan ini merupakan persediaan yang mencakup seluruh alat-alat yang dibutuhkan oleh kantor dimana jenisnya di luar barang cetakan. Contohnya kertas, pena tulis, tinta printer dan lainnya.

2. Persediaan Barang Cetakan

Persedian barang cetakan merupakan persediaan dimana jenis barangnya merupakan barang-barang cetakan seperti tiket-tiket transaksi, stempel, slip setoran, slip penarikan, aplikasi transfer dan lainnya.

3. Persediaan Souvenir

Jenis barang yang terdapat pada persediaan souvenir ini adalah barang yang di sediakan oleh PT Bank Muamalat Indonesia untuk para nasabah. Jenis barang ini akan diberikan kepada para nasabah yang membuka tabungan atau deposito atau nasabah utama. 
4. Persediaan ATM

Persediaan ATM digunakan untuk mengelola stok kartu ATM pada PT Bank Muamalat Indonesia cabang pekanbaru.

5. Persediaan Buku Cek dan Bilyet Giro Buku cek dan Bilyet Giro pada PT. Bank Muamalat Indonesia termasuk kedalam kategori persediaan. Persediaan ini akan dibebankan ketika nasabah meminta buku cek atau bilyet giro melalui customer service.

6. Persediaan Materai

Materai juga termasuk kedalam persediaan. Sama seperti persediaan lainnya materai akan menjadi beban ketika ada permintaan materai dari departemen yang ada pada PT. Bank Muamalat Indonesia cabang Pekanbaru.

\section{b. Deskripsi Umum Sistem Yang dikembangkan}

Sistem baru yang akan dibangun dikembangkan menggunakan bahasa pemrograman visual basic dan Database Management System (DBMS) MySQL. Sistem ini mempunyai fungsi untuk pencatatan order barang yang nantinya akan di setujui oleh Operation Manager. Pada sistem yang baru ini juga terdapat pencatatan barang masuk, pemakaian ATK, serta pelaporan bulanan. Sistem ini juga bisa melihat pemakaian ATK pada setiap divisi yang ada pada PT.Bank Muamalat Indonesia cabang Pekanbaru.

Adapun fungsi dari sistem informasi persediaan alat tulis kantor yang akan dibuat adalah untuk :

1. Mempermudah staff sarana dan logistik untuk mengetahui stok akhir barang di gudang persediaan.

2. Mempermudah dalam proses pembukuan persediaan alat tulis kantor kedalam sistem akutansi perusahaan.

\section{c. Uraian Prosedur}

Langkah dalam pembuatan uraian prosedur mengacu kepada prosedur yang ada pada sistem persediaan ATK sebagai berikut:

1. Departemen yang membutuhkan alat tulis kantor membuat surat permintaan yang diajukan kepada sarlog.

2. Bagian sarlog meng-input data permintaan kedalam sistem informasi persediaan alat tulis kantor untuk disetujui oleh Operation Manager.

3. Operation Manager akan mengecek permintaan. Jika permintaan disetujui maka data persetujuan akan tersimpan kedalam database. Jika permintaan tidak disetujui maka form permintaan dikembalikan kepada bagian sarlog untuk dekembalikan kepada departemen yang meminta.

4. Sarlog akan mencetak data permintaan yang telah disetujui dan melakukan pengecekan terhadap stok persediaan ATK. Jika stok masih tersedia maka barang ATK akan langsung didistribusikan.

5. Jika persediaan tidak ada maka sarlog akan melakukan input data PO yang nantinya disetujui oleh Operation Manager .

6. PO yang telah disetujui oleh Operation Manager diserahkan kepada supplier, dan supplier mengirimkan barang ATK sesuai dengan PO.

7. Ketika barang ATK masuk bagian sarlog akan meng-input data barang masuk dan disimpan kedalam database.

8. Setiap akhir bulan laporan persediaan alat tulis kantor akan dicetak dan dilaporkan kepada Operation Manager.

Arus sistem informasi dapat dilihat pada aliran sistem berikut ini sebagai berikut: 


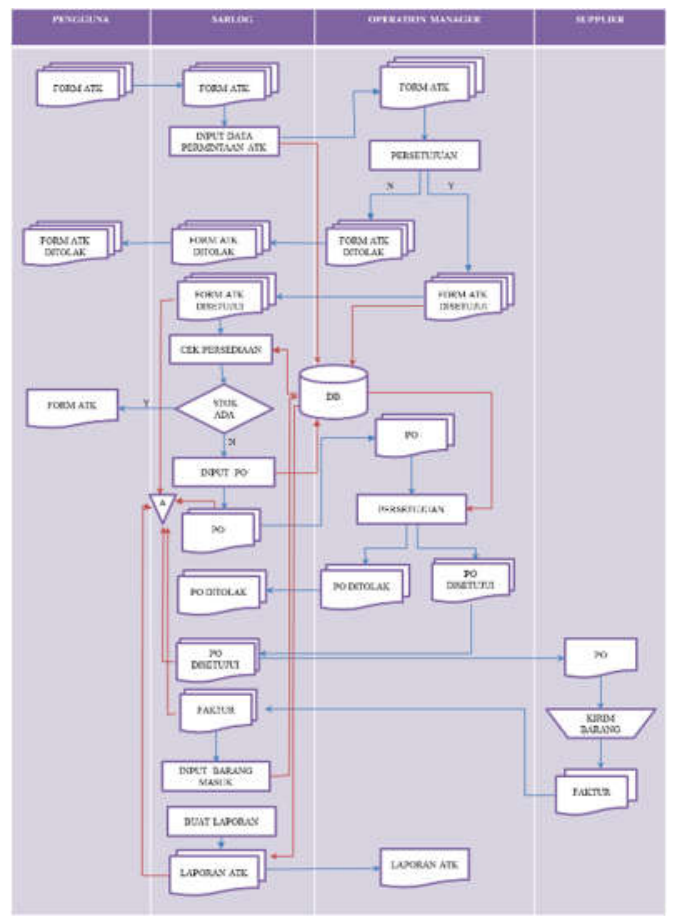

Gambar 2. Aliran Sistem Inventori

\section{d. Rancangan Data Flow Diagram}

\section{Diagram Konteks}

Diagram Konteks digunakan untuk menggambarkan sistem pengolahan data secara garis besar atau menyeluruh, diagram konteks ini dirancang untuk memperhatikan masukan yang dibutuhkan oleh sistem dan keluaran yang dihasilkan oleh sistem itu sendiri.

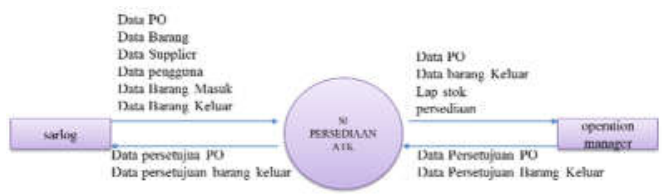

\section{Gambar 3. Diagram Konteks SI Alat Tulis Kantor}

\section{DFD level 1}

DFD level 1 ini berfungsi untuk merinci masing masing proses yang ada pada diagram konteks. DFD level 1 ini terdiri dari 4 proses yaitu, proses login, proses input master barang, proses transaksi barang masuk, dan transaksi barang keluar.

DFD level 1 dapat dilihat pada gambar 4.3 berikut.

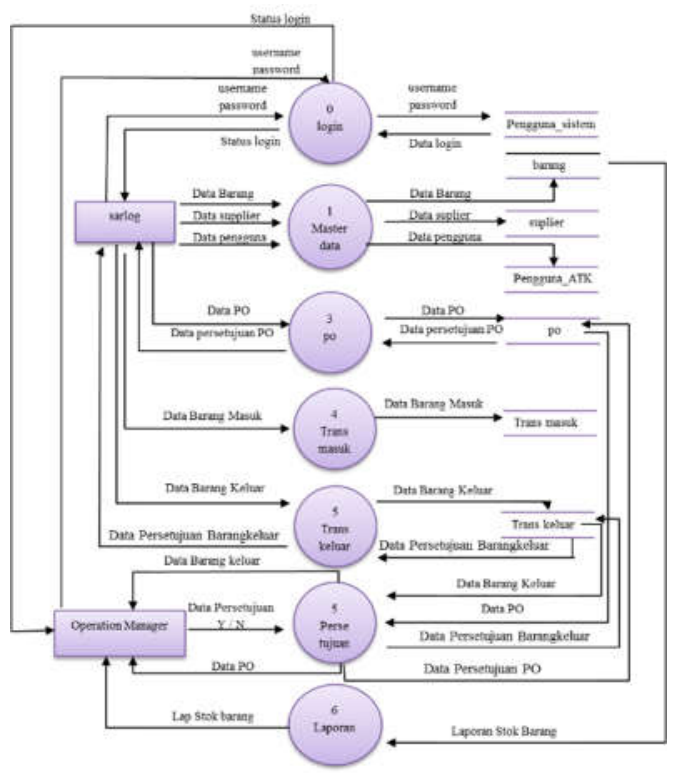

Gambar 4. Data Flow Diagram level 1

\section{e. Perancangan Sub Sistem Manajemen Data}

Data yang digunakan dalam pendukung keputusan ini ditampung dalam basis data yang terintegrasi dengan komputer. Basis data dirancang agar data yang berkaitan dapat teroganisir dan tersimpan dengan baik sehingga memudahkan dalam pencarian dan manipulasi data.

\section{Entity Relationship Diagram}

Entitas yang terlibat didalam sistem pendukung keputusan ini adalah entitas barang, pengguna, supplier. Hubungan antar entitas tersebut dapat digambarkan dalam entity relation diagram pada gambar berikut. 


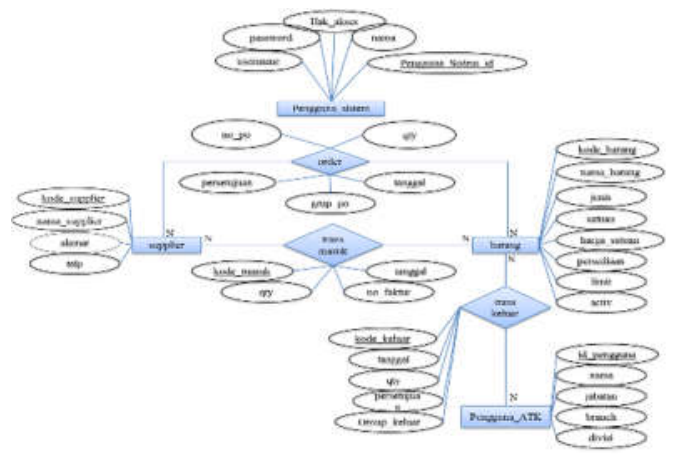

Gambar 5. Rancangan ER-D

\section{Relasi Antar Tabel}

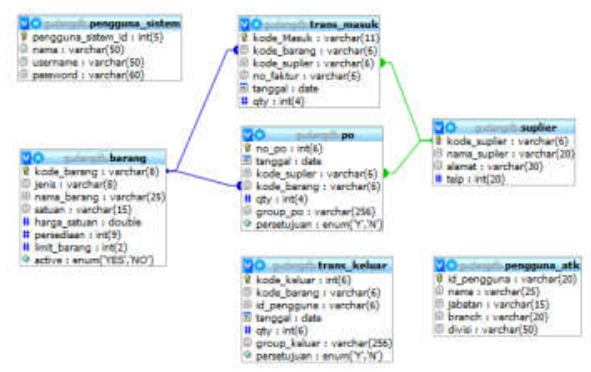

Gambar 6. Relasi Antar Tabel

\section{F. Implementasi}

1. Tampilan Halaman Utama

Halaman utama merupakan halaman yang akan muncul ketika aplikasi pertama sekali dijalankan.

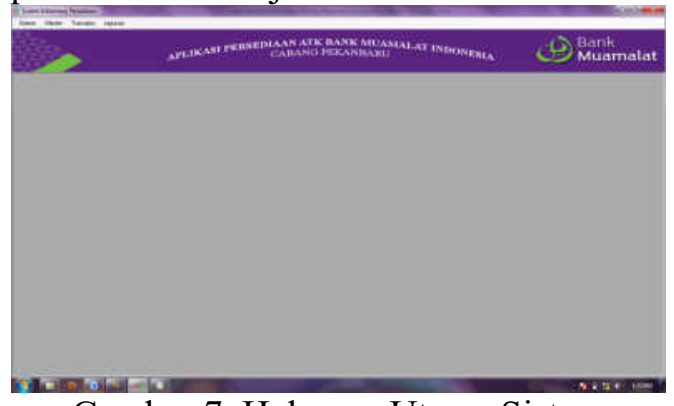

Gambar 7. Halaman Utama Sistem

2. Halaman Login
Halaman login merupakan halaman yang digunakan agar bisa mengakses menu menu didalam sistem.

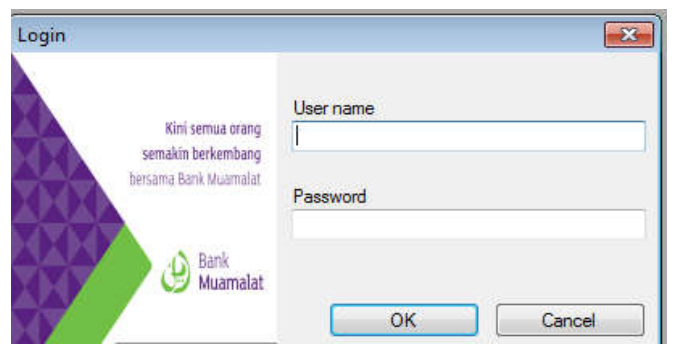

Gambar 8. Halaman Login

\section{Halaman Transaksi Barang Masuk}

Halaman transaksi barang masuk ini digunakan untuk melakukan transaksi ketika barang ATK masuk ke dalam persediaan gudang. adapun tampilan dari halaman transaksi masuk ini bisa dilihat pada gambar berikut ini.

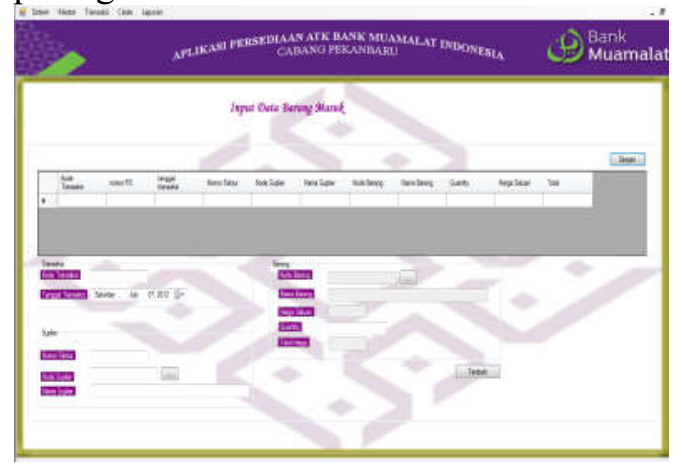

Gambar 9. Halaman Transaksi Barang Masuk

4. Halaman Transaksi Barang Keluar

Halaman ini digunakan untuk melakukan data transaksi ATK yang keluar ketika ada permintaan ATK. Tampilan dari halaman ini dapat dilihat pada gambar berikut. 


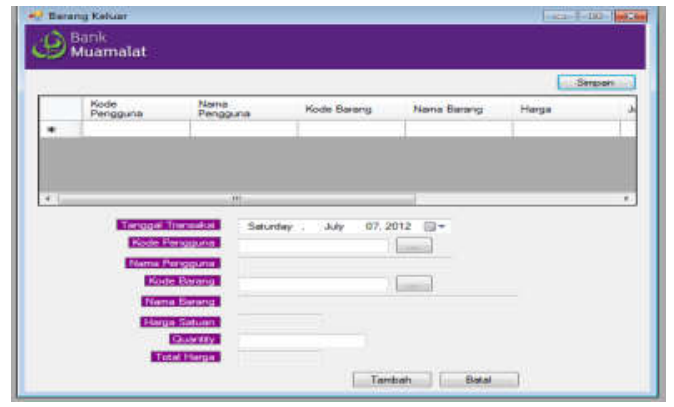

Gambar 10. Transaksi Barang Keluar

\section{Halaman Laporan Stok}

Halaman laporan stok digunakan untuk mencatak laporan stok persediaan ATK untuk dijadikan lampiran dalam pelaporan persediaan setiap tutup buku akhir bulan.

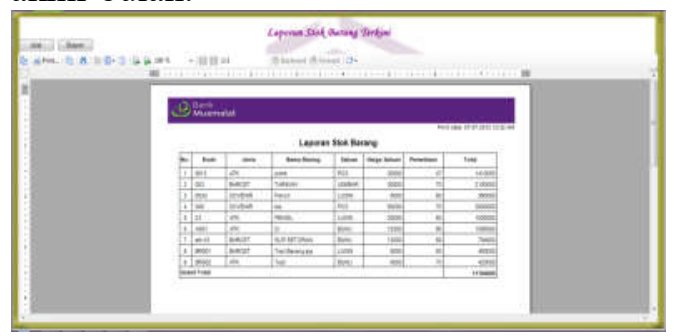

Gambar 11. Halaman Laporan Stok

\section{PENUTUP}

\section{a. Kesimpulan}

Berdasarkan hasil penelitian, analisis dan pembangunan sistem informasi persediaan alat tulis kantor di atas maka dapat diambil kesimpulan sebagai berikut:

1. Telah dibuatkan sistem informasi persediaan alat tulis kantor pada PT. Bank Muamalat Indonesia cabang pekanbaru

2. Sistem informasi persediaan alat tulis kantor ini sangat membantu dalam mengelola persediaan ATK yang ada.

\section{b. Saran}

Setelah meneliti dan menuangkannya kedalam penelitian ini maka dapat diberikan saran untuk persediaan alat tulis kantor pada PT.Bank Muamalat Indonesia cabang Pekanbaru sebagai berikut:

1. Sistem yang dikembangkan kedepannya harus bisa diakses oleh semua kru pengguna alat tulis kantor sehingga bagian sarlog hanya tinggal melihat data permintaan saja.

2. Sistem yang ada belum terkoneksi kedalam jaringan komputer di kantor sehingga kedepannya bisa dikembangkan menjadi sistem yang berbasis client server.

\section{DAFTAR PUSTAKA}

Al Bahra Bin Ladjamuddin B, 2004. Konsep sistem basis data dan implementasinya.

Yogyakarta : Graha Ilmu.

Bunafit Nugroho, 2009. Panduan Lengkap Menguasai Perintah SQL. Jakarta :MediaKita.

Dodit Suprianto 2010. Membuat Aplikasi Desktop Menggunakan MySQL \& VB.NET Secara Profesional.Jakarta :MediaKita.

Jogiyanto, HM. 2005.Analisis dan Desain Sistem Informasi.Yogyakarta :Andi Offset.

Kristanto, Andri, 2003. Perancangan Sistem Informasi dan Aplikasinya.Jakarta :

Gava Media.

Leod, RaymonMc, 2005. Management information System. Jilid II. New Jersey Prentice Hall. 
Leman,1998. Metode Pengembangan Sistem Informasi. Jakarta : Elex Media Komputindo

Nugroho, Adi 2005.Analisis Dan Pernacangan System Informasi Dengan

Metodologi Berorientasi Objek. Bandung :Informatika.

Sutabri, Tata. 2004. Analisa Sistem Informasi.Yogyakarta :Andi Offset

Silberschatz, A. 2002. Database System Consepts Fourth Edition. New York : McGraw-Hill Companies

Suryanto Suharli, 2005. Membangun Aplikasi Berbasis Windows Dengan Visual
Basic.Net. Jakarta : Elex Media Komputindo.

http://id.wikipedia.org/wiki/sistem_inform asi

http://digilib.ittelkom.ac.id/article/definisipersediaan 